Рина Павловна Усикова - Учител и Пријател

Emilia Crvenkovska (Skopje, Macedonia)

\title{
Rina Pavlovna Usikova - Teacher and Friend
}

Не случајно во насловот двете карактеристики на нашата славеничка се напишани со голема буква: зашто таа е Учител со големо У и пријател со големо П. Освен тоа таа е и научник, лексикограф, преведувач, интелектуалец, човек со огромно знаење, богат дух и голема харизма.

Рина Павловна Усикова ја запознав во Скопје, пред моето доаѓање за лектор по македонски јазик на Московскиот државен универзитет «Ломоносов» во учебната 1986-1987 год. На прв поглед бев исплашена од оваа авторитетна жена и за малку ќе се покаев што се пријавив да работам на Московскиот универзитет. Но, веднаш по доаѓњето во Москва во септември, кога таа и нејзиниот сопруг Чеслав Викентјевич ме пречекаа на Киевската железничка станица со китка цвеќе и ми помогнаа да се сместам во општежитието на Шаболовка, студениот впечаток почна да се стоплува. Таа како извонреден организатор и домаќин веднаш се погрижи да не се чувствувам осамено во оваа далечна земја, сред милионски град.

Веднаш почнаа работните активности и Рина Павловна ми побара план за работа за цел семестар. Сепак, бев млад асистент од Скопскиот универзитет без многу работно искуство. Но, исполнителна и подготвена да учам. Седнав и го сработив бараното, па почна меѓу нас да се развива и професионална блискост. Ми помагаше да сфатам дека пристапот во работа со странци треба да се разликува од оној на којшто бев навикната во работата со моите македонски студенти. Ме подучи да воведам и нови содржини освен граматичките, односно културолошки теми, како и текстови преку кои студентите поблиску ќе се запознаат со мојата земја. Ми предочи и колку е важно да се има еден понеформален однос со студентите и да се дружиме и во вонфакултетски услов, што не беше тешко со мојата мала и одбрана група од пет студенти кои потоа ми станаа и пријатели.

Толку околу првиот човечки впечаток.

Сега малку за Рина Павловна, научник и педагог. Знаејќи ја од порано нејзината научна работа почнав да се запознавам повеќе со нејзините трудови. И со почетоците на македонистиката на МГУ. Таа често со огромна почит и благодарност го споменуваше својот ментор С.Б. Бернштејн којшто ја упатил токму на македонистиката, па еднаш и ме испрати во Институтот за руски јазик на Кропоткинска да 
слушам негово предавање на една конференција и да се уверам дека тој е навистина човек за восхит.

Рина Павловна за мене е научник и педагог со високи научни и етички вредности, што е пример за сите нас што учевме од неа. Нејзиниот придонес за македонистиката е повеќе пати истакнуван. Таа почнува да се занимава со македонскиот јазик уште при изработката на нејзината кандидатска дисертација «Морфология имени существительного и глагола в македонском литературном языке» (1965) одбранета под менторство на С.Б. Бернштејн. По повеќе децениски истражувања на македонскиот јазик од различни аспекти, таа ја одбранува и докторската дисертација на тема «Македонский литературный язык как предмет славистики и балканистики» во 2005.

Таа е автор на низа значајни трудови за македонскиот јазик, како граматика на македонскиот јазик: «Македонский язык. Граматический очерк, тексты для чтения с комментариями и словарем» Скопје 1985 (второ дополнето издание: Скопје 2000); «Грамматика македонского литературного языка», Москва 2003 и др. Има објавено над 120 трудови во кои се обработуваат разни теми со македонска јазична проблематика. Во нејзините статии посветени на македонскиот јазик таа обработува проблеми поврзани со морфологијата на глаголот, за разни категории кај именските зборови, акцентот во македонскиот јазик, социолингвистички проблеми посветени на нормата, на јазичната ситуација, на етнојазичните и етнокултурните проблеми во македонскиот јазик и сл. потоа се осврнува на јазикот на низа значајни автори од македонскиот XIX (Пејчиновиќ, Мисирков) и XX век (Конески). Во низа трудови се осврнува на балканистичката проблемтика, како и на контрастивни македонско-бугарски и македонско-руски сопоставувања.

Рина Усикова е и докажан лексикограф со капитални лексикографски изданија: «Македонско-руски речник. Македонско русский словарь», 1-3, Скопје 1998 (соавтори: 3. Шанова, М. Поварницина, Е. Верижникова, ред. Р. Усикова). Потоа, во 2003 година, и во Москва излегува «Македонско русский словарь. Македонско-руски речник» од истата група автори под редакција на нашата славеничка. Преку овие изданија се покажува и организаторската способност на Рина Павловна да обедини екипа лексикографи и одлично да организира тимска работа.

Усикова е автор и на енциклопедиски одредници и поглавја за македонскиот јазик како: «Македонский язык» во «Славянские языки», Москва 1977; «Македонский язык» во «Основы славянского языкознания. Часть 2. Славянские языки», Санкт-Петербург 1998 и др.

Посебно треба да се истакне педагошката дејност на Р. Павловна Усикова. Благодарение на нејзините заложби и под нејзино раководство од 1975 на Филолошкиот факултет при Московскиот државен универзитет «Ломоносов» се отвораат специјалистички студии по македонски јазик и литература. Од оваа студиска група досега излегле над педесет дипломирани македонисти. Била ментор и на неколку аспиранти македонисти, а од нејзините студенти македонистиката потоа се прошири и на универзитетите во Воронеж и во Перм.

Дејноста на Рина Павловна треба да се гледа и како мост меѓу два јазика, меѓу две култури. Тука мислам и на нејзиниот влог во ширењето на рускиот јазик и култура во Македонија. Предаваше руски јазик на Филолошкиот факултет «Блаже Конески» во Скопје од 1992 до 1997 година, при што на генерации студенти им пренесуваше знења од рускиот јазик и култура. Овој престој го искористи и за низа значајни истражувања и учества на конференции, предавања и сл. 
Рина Усикова ѝ приближи на руската читателска публика повеќе дела од македонски автори преку преводите на руски на: раскази од Ѓ. Абаџиев, Т. Момировски, С. Дракул, драми од Г. Стефановски, научни трудови од Б. Конески и од Б. Видоески и др. Таа е и автор на повеќе предговори кон изданија посветени на Македонија.

Поради исклучителните заслуги за македонистиката, Рина Павловна стана член на Македонската академија на науките и уметностите од 1979 година, почесен доктор на Универзитетот «Св. Кирил и Методиј» од 1996 година, а во 2007 година се здоби и со високото државно одликување Медал за заслуги за Република Македонија.

И сега уште малку за човечката димензија на нашето дружење. Има научници со кои можеш да зборуваш само за наука. Но има научници - луѓе од крв и месо, со душа, со огромна широчина и култура, познавање на многу области од литература, историја, фолклор, филм. И уште згора на тоа љубител на хедонистички уживања што ги споделувавме заедно, со нашите сопрузи и со други пријатели, те во Русија со боршч и руска вотка, прекрасните блини што ги прави таа со објаснување дека се јадат на Масленица и сета симболика што ја носат, до седенките што сме ги имале во Скопје и Охрид со охридска пастрмка, жолта ракија и македонското вино «Т'га за југ» кое Рина посебно го сака оти ја потсетува ем на Миладинов и на Охрид, ем на Македонија. И така, богати се спомените од едно трајно пријателство со драгата наша славеничка Рина Усикова.

Драга Рина Павловна, за многу години!

Сведения об авторе:

Емилија Црвенковска,

Доктор по филологија

Професор

Филолошки факултет «Блаже Конески»

Универзитет «Св. Кирил и Методиј»
Emilia Crvenkovska,

Doctor of Philology

Professor

Faculty of Philology "Blaze Koneski"

University "St. Cyril and Methodius" 